\title{
Gastronomi Sektörü Meslek Uzmanlarının Çalışanlardan Mesleki Beklentileri Ve Gastronomi Eğitimi İle İlgili Düşünceleri
}

\section{Vacational Expectations Of Gastronomy Professionals From Employees And Their Evaluations Relating To Gastronomy Education}

\author{
Kadriye Alev AKMEŞE, Türkiye, alevakmese@gmail.com \\ Orcid No: 0000-0002-3826-9684 \\ Esat ÖZATA, Beykent Üniversitesi, Türkiye, esatozata@beykent.edu.tr \\ Orcid No: 0000-0002-8175-1361 \\ Ümit SORMAZ, Necmettin Erbakan Üniversitesi, Türkiye, usormaz@erbakan.edu.tr \\ Orcid No: 0000-0001-7514-1500
}

\begin{abstract}
Öz: Dinamik bir sektör olan turizm, hizmete dayalı ve sosyal yapısı ile etkileşim halinde olduğu birçok alt sektörü doğrudan ya da dolaylı olarak etkilemektedir. Küreselleșme ve gelişsen teknoloji ile farkındallk düzeyi artan turistlerin talep ve beklentileri de değişkenlik göstermeye başlamıştır. Bu değişken talepleri karşısında turistlerin memnun olmalarını ve iyi bir tatil deneyimi edinmelerini sağlamak, yalnızca otellerin fiziki imkanları ile mümkün olmamaktadır. Nitelikli personel, misafir memnuniyeti için en önemli unsurlar arasındadır. Bu çalışmada, öncelikli olarak turizmin popüler türlerinden olan gastronomi sektöründeki meslek uzmanlarının gastronomi alanında çalışanlardan mesleki beklentileri ve bu beklentileri etkileyen unsurlar incelenmiş̧ir. Aynı zamanda meslek uzmanlarının sektörün gereklilikleri doğrultusunda gastronomi eğitimi ile ilgili düşüncelerini ortaya koymak amacı ile yapılmıştır. Bu şekilde gastronomi alanında eğitim alan ve faaliyet gösteren bireylerin nitelikleri konusunda değerlendirmeler yapılmaya çalışılmış̧ır.

Çalışmanın örneklemi Türkiye'de Istanbul ilinde turizm işletmelerinin idari ofislerinde, yiyecek içecek bölümlerinde yönetici olarak çalışan ve ankete katılmak için gönüllü olan 407 meslek uzmanindan oluşmaktadır. Bu çalışmada nicel araş̧tırma yöntemlerinden olan anket veri toplama tekniği ile bilgi edinilmiştir. Veri analizi için "Frekans" ve "ANOVA" testleri yapılmıştır.

Çalışma sonucunda, gastronomi sektörü meslek uzmanlarının sektör çalı̧̧anlarından beklentilerinin başında mesleki deneyime sahip olmaları ve gayretli olmalarının geldiği görülmüştür. Aynı zamanda çalışanların yiyecek ve içecekler konusunda mesleki bilgiye sahip olmaları önemlidir. Gastronomi sektörü meslek uzmanları, gastronomi ve mutfak sanatları bölümlerindeki eğitmenlerin reel sektöre ilișkin çok iyi bilgi sahibi olmadıklarına inanmaktadır. Ayrıca bu alanda eğitim alan öğrencilerin staj ve iş başında eğitimi almalarının kariyerleri için faydalı olacağını öngörmektedirler. Bu sonuçların ıșığında, öğrencilere deneyim seviyelerini arttırmaları için staj olanakları ve iș bașında eğitim kursları verilmesi önem tașımaktadır. Bu sayede öğrencilerin yiyecek-içecek kursları veya eğitimleriyle becerilerini geliştirmeleri konularında desteklenmeleri önerilmektedir. Aynı zamanda üniversitelerin gastronomi bölümlerinde istihdam edilecek ögretim üyelerinin, gastronomi endüstrisinde pratik bilgi, beceri ve deneyime sahip kişiler arasından seçilmesinin gerekliliği vurgulanmışıtır.
\end{abstract}

Anahtar Sözcükler: Turizm, Gastronomi, Mesleki Beklenti, Gastronomi Eğitimi

JEL Sinfflandirmast: L83, J21, L52

\begin{abstract}
Tourism as a dynamic sector directly or indirectly affects various sub-sectors that it is in interaction with due to its service-oriented and social structure. Along with the increase in their awareness levels thanks to globalization and advancing technology, the demands and expectations of tourists have started to grow different. In response to these variable demands, physical facilities of the hotels fall short of ensuring that the tourists are satisfied and have a good holiday experience. A qualified staff is among the most important elements for guest satisfaction. In the current study, primarily what the professionals in the gastronomy industry, which is one of the most popular types of tourism, professionally expects from the employees in the related industry and the factors that affect these expectations are discussed. At the same time, the current study has been carried out with the purpose of revealing the views of the professionals on gastronomy education in line with the requirements of the industry. In this way, it is attempted to make evaluations about the qualifications of individuals who have studied and currently work in the field of gastronomy.

The research sample is comprised of 407 respondents who work as manager in administrative offices of the food \& beverage departments of tourism enterprises in Istanbul, Turkey and have volunteered to be involved in the survey. Questionnaire which is a data collection tool in quantitative research methods is employed in the current study to collect data. The research data are analyzed via "Frequence" and "ANOVA" tests.

As a result of the study, it has been concluded that the professionals in the gastronomy industry expect from the employees in the sector to have professional experience and diligence at work. It is also important that employees have professional knowledge of food and beverages. Professionals in the gastronomy industry believe that the lecturers in the departments of gastronomy and culinary arts do not have adequate knowledge of the real sector. In addition, it is predicted by the professionals that internship and on-the-job trainings for the students studying in this field will be beneficial for their careers.

In the light of these results, it is important to provide internship opportunities and on-the-job training courses for the students to increase their level of experience. In this way, it is recommended to encourage students to develop their skills through courses or trainings on food and beverages. At the same time, it is emphasized that the faculty members to be employed in the gastronomy departments of universities should be selected among those who have practical knowledge, skills and experience in the gastronomy industry.
\end{abstract}

Keywords: Tourism, Gastronomy, Professional Expectation, Gastronomy Education JEL Classification: L83, J21, L52

Makale Gecmiși / Article History Başvuru Tarihi / Date of Application Kabul Tarihi / Acceptance Date
: 13 Ağustos / August 2019

: 2 Aralık / December 2019 


\section{Introduction}

Tourism is one of the fastest growing sectors with its wide coverage in economies. As of the beginning of the twenty-first century, the tourism industry has been demanded more than ever and come to the forefront with a structure characterized by a conscious tourist profile (Hall et al., 2004: 3, Kadir \& Karim, 2009: 51). Tourism is basically a human mobility. In the broadest sense, it is a term that encompasses people moving away from their permanent resident places with the aim of staying in a different place temporarily and all the activities related to this mobile process (Lickorish \& Jenkins, 1997: 33).

With the impact of advanced technology and globalization, the diversity in tourism mobility has expanded. Individuals have started to engage in tourism activities more frequently and comfortably with the increase in transportation opportunities and decrease in costs besides the working conditions improved and the concept of leisure time coming into more prominence. Thanks to easier access to information, individuals have begun to search for and experience alternative types of tourism in order to gain different experiences during their holidays. In essence, gastronomy is a type of experience that has always been present in tourism but has gained popularity with individuals' seeking for new tourism alternatives (Gheorghe et al., 2014: 12).

Gastronomy, which can be expressed as the interaction of everything related to eating and drinking (Hegarty and O'Mahony, 2001; Santich, 2004; Hegarty, 2005; Hegarty and Antun, 2007), is defined as "enjoying good food and drink", or, as a comprehensive discipline embracing "everything which is eatable and drinkable" (Scarpato, 2003: 52). Santich (2004) defines gastronomy as "offering proposals related to what, where, when, in which combination and how to eat and drink depending on historical, cultural and environmental effects, and making guidance, accordingly." Gastronomy, which is closely related to local and regional culture, is in interaction with many disciplines such as history, sociology, philosophy, chemistry, nutrition, anthropology and biology. With this aspect, gastronomy is an interdisciplinary activity (Kivela \& Crotts, 2006: 354-355). Considering that consumption comprises a significant part of tourism behaviors (Aydin, 2015: 1), the fact that food and beverage-related activities have become a special area of interest besides only satisfying physiological needs of individuals has attracted the attention of tourism professionals and it has paved the way for a new tourism activity called "gastronomy tourism" (Şahin, 2015: 55).

Food is one of the major expenditure items of tourism activity. During tourism activities, a significant portion of budget is allocated to food and beverage expenses. For this reason, individuals planning tourism activities are also searching for the local tastes in the regions they will visit in order to get a good return for their expenses and to have a satisfactory tourism experience (Gheorghe et al., 2014: 14). Thus, one of the most costly aspects of tourism mobility turns into entertaining and delicious experience. In this respect, food and tourism activity is in close interaction. There is also a close connection between food and local culture. Local delicacies are of great importance for a region's cultural history and intangible attractiveness. One of the important factors that increase regional attractiveness within the scope of tourism activities is local cuisine. Individuals who wish to get to know to cultural history by way of experiencing local delicacies consider the food as the main driver of tourism mobility (Sandybayev, 2016: 2). Gastronomic attributes and gastronomy tourism are an important type of experience in the context of sustainability and diversification of tourism and the preservation of cultural heritage and its transfer to future generations.

The attractiveness of gastronomy should be utilized to ensure the growth and enhance the diversity of the tourism industry. Furthermore, it is of great importance to develop gastronomy tourism in order to prevent temporal and spatial concentration, to ensure the sustainability of regional tourism and to attract the tourist mass, called 'qualified tourists' to the destination (Durlu-Özkaya and Can, 2012: 30).

The economic, social and technological developments within the last fifty years in the world have driven significant changes in the perception and implementation of the concept of tourism. The changes and transformations in question have been observed not only in qualitative (e.g. the increase in number of tourists and the increase in tourism revenues) but also in quantitative aspects (e.g. tourism demand and preferences) in the tourism industry (Y1lmaz and Gürol, 2012: 23). Within the tourism industry, gastronomy is particularly considered as a discipline which changes and transforms at all times, renews itself continuously and also embodies the generic rules on food and beverages (Şahin, 2015: 41). Therefore, not only the sector and the sector representatives and but also the employees in the sector should improve themselves and keep up with the changes continuously.

In order to ensure the sustainability of gastronomy tourism and attract qualified tourists to destinations, the qualifications of the employees and units operating in the field of gastronomy are of vital importance. In this context, the current study will try to put forward the views, expectations and evaluations of sector professionals towards the individuals working and receiving education to work within the gastronomy industry.

\section{Literature Review}

Reviewing the comprehensive literature on tourism and gastronomy industry, high turnover rates rank at the top as one of the most striking findings (Ghiselli et al., 2001: 22; Pelit et al., 2017: 65-66, Tensone and Ricci, 2012: 141). This situation leads sector managers to be more careful and selective about employees. In addition to this general finding on the recruitment and retention of employees in the tourism industry, there are also some studies in the literature where different findings can be observed. 
Kim (2008) investigated the hotel managers' employee preferences and needs for kitchen departments in big hotels in New Zealand. It was observed in the research that the priority in employee preferences was on employees' personality traits. The managers preferred those who have high organizational commitment and strong communication skills. Employee personality was followed by experience and educational background.

Gümüş, Arı and Bakırtaş (2010) examined the employee preferences of five-star hotels in Bursa, Turkey. It was concluded in the research that the candidate employees' having adequate knowledge and skills about the unit they will work was the number one required qualification in employee preferences. Furthermore, the fact that the employees have had education in their fields, and that they are compatible with the service industry, are sociable and have high communication skills are the findings showing parallelism with the other studies in literature.

In the field study carried out by Chan and Kuok (2011) in Macau, it was found that managers primarily preferred in employment process the individuals who were sociable and effective in social and human relations. This result supports the findings in Kim's (2008) research. The fact that the tourism industry produces service and that the employees in the sector are in direct communication with customers justify the sensitive approach of employers.

In a research conducted in Orlando, Florida by Tesone and Ricci (2012), sector managers and professionals indicated that they have moderate level of satisfaction in finding qualified employees. In addition, the managers stated that they prefer hiring individuals who have secondary and higher education in their fields. This finding highlights the importance of education in employee preferences.

Findings of the research conducted by Pelit, Soybali and Ak (2017) in Afyonkarahisar, Turkey show that job experience bears importance in employee preferences and the likelihood of being selected for a vacancy increases in line with the level of experience. In addition, it is concluded in the research that there are challenges in finding qualified and trained personnel, which shows parallelism with the findings of Tensone and Ricci's study.

As a result of the researches in literature, it has been revealed that personality traits reflecting strong social relationship skills are of great importance in employee preferences because the tourism industry produces service as a main product. Besides, managers attach importance to employee loyalty and commitment in order to reduce staff turnover rate. For the above-mentioned reasons, employee personality becomes an important factor in hiring process. Secondly, it is observed that individuals who have experience in their field of work are more likely to be preferred. This matter is important since it facilitates employee adaptation and minimizes training costs. The fact that employees have secondary and higher level education in their fields is another important matter to which managers pay attention. Consequently, the important elements in employee preferences can be listed as the candidate's personality traits, field experiences and the education on the field.

\section{Methodology}

Activities carried out towards the applied research within the sector, interpretation of data gathered, analysis and overall evaluations are going to be mentioned under this heading.

\subsection{Research Purpose}

The purpose of the current study is to reveal the professional expectations of the professionals in the tourism and gastronomy industry from the employees in line with the requirements of the sector and to discover the factors affecting the expectations in question. Besides, it is aimed to reveal the views of professionals on gastronomy education within the framework of gastronomy students who are the potential workforce for the sector. In the light of the findings obtained in this direction, professional qualifications that will ensure customer satisfaction, which is necessary for the development of the sector and the sustainability of gastronomy tourism, will be determined and recommendations will be proposed, accordingly.

\subsection{Population and Sample}

Research population is composed of professionals working as manager in the administrative offices and food and beverage departments of tourism enterprises in Istanbul, Turkey (Table 1). In this context, the sample consists of 407 professionals working as manager in the administrative offices and food and beverage departments of tourism enterprises in Istanbul, Turkey and having volunteered to be involved in the survey.

Table 1. Tourism Enterprises in Istanbul, Turkey

\begin{tabular}{|l|c|c|c|}
\hline & $\begin{array}{c}\text { With Tourism } \\
\text { Operation License }\end{array}$ & $\begin{array}{c}\text { With Investment } \\
\text { License }\end{array}$ & TOTAL \\
\hline & $\mathrm{n}$ & $\mathrm{n}$ & $\mathrm{n}$ \\
\hline 5 Star Hotel & 103 & 29 & 132 \\
\hline 4 Star Hotel & 126 & 39 & 165 \\
\hline 3 Star Hotel & 124 & 36 & 160 \\
\hline $\begin{array}{l}\text { Food \& Beverage and Entertainment } \\
\text { Facilities }\end{array}$ & 430 & 20 & 450 \\
\hline
\end{tabular}


In the scope of the study, three, four and five-star hotels and dining/entertainment venues in Istanbul were selected for data collection.

\subsection{Questionnaires and Data Collection}

Questionnaire, a data collection technique in quantitative research methods, was used in the current study. The scale which was used in previous researches following the verification of its validity and reliability (Kim, 2008) was applied in the current study. The questionnaire form consists of 7 parts including questions and cases to measure the respondents' demographic characteristics, professional background and experiences, information on current work positions, employee qualifications sought by the professionals in the sector, views of the sector professionals on the universities' gastronomy and culinary arts departments, expectations of professionals from the students of the departments of gastronomy and culinary arts and the professionals' views on graduation from the related department. The questionnaires were applied to 450 individuals randomly selected among the managers working in the administrative offices and food and beverage departments of the tourism enterprises that volunteered to participate in the research. Following the conduct of the questionnaires, it was reported that 407 questionnaire forms were eligible to be included into analysis process.

Since the population size was greater than 10.000, the formula of unrestricted sampling was used for the determination of sample size (Ural and Kılıç, 2013: 47). As the sample size was calculated taking into consideration the sampling error of $5 \%$ and the confidence level of $95 \%$, the number required for a large population was found 384 (Büyüköztürk, 2010; Ural and Kılıç, 2013: 47; Can, 2014: 30). With regard to the confidence level, sufficient number of respondents was reached with 407 individuals, who volunteered to participate in the survey.

\subsection{Data Analysis}

The data obtained in the study were analyzed via statistical package program. "Frequence", "Chi-Square" and "ANOVA test" were performed for data analysis.

\section{Findings}

Having analyzed Table 2 which presents the demographic characteristics of respondents, it was observed that $78.4 \%$ of the respondents are male and $21.6 \%$ are female, $64.1 \%$ are within the age range of $31-64,56.5 \%$ are married and $42.5 \%$ are primary school graduate. As the data were analyzed statistically, the difference in respondents' age distribution ( $\mathrm{p}$ $<0.05)$, marital status $(\mathrm{p}<0.01)$ and education $(\mathrm{p}<0.05)$ was found to be significant.

Table 2. Demographic Findings

\begin{tabular}{|c|c|c|c|c|c|c|c|c|c|c|c|c|}
\hline & \multicolumn{2}{|c|}{ 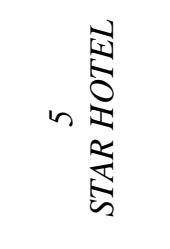 } & \multicolumn{2}{|c|}{ 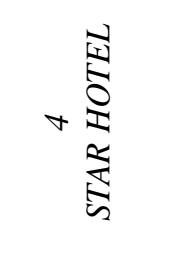 } & \multicolumn{2}{|c|}{$n \underset{\frac{1}{5}}{\frac{N}{\sigma}}$} & \multicolumn{2}{|c|}{ 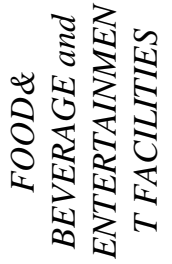 } & \multicolumn{2}{|c|}{$\frac{\mathfrak{z}}{6}$} & \multirow[t]{2}{*}{$X^{2}$} & \multirow[t]{2}{*}{$p$} \\
\hline & $\mathrm{n}$ & $\%$ & $\mathrm{n}$ & $\%$ & $\mathrm{n}$ & $\%$ & $\mathrm{n}$ & $\%$ & $\mathrm{n}$ & $\%$ & & \\
\hline Gender & & & & & & & & & & & & \\
\hline Female & 20 & 31.3 & 21 & 20.8 & 18 & 17.5 & 29 & 20.9 & 88 & 21.6 & 4.634 & 0.201 \\
\hline Male & 44 & 68.8 & 80 & 79.2 & 85 & 82.5 & 110 & 79.1 & 319 & 78.4 & & \\
\hline Age & & & & & & & & & & & & \\
\hline $18-30$ old & 15 & 23.4 & 18 & 17.8 & 23 & 22.3 & 41 & 29.5 & 97 & 23.8 & & \\
\hline 31-64 old & 35 & 54.7 & 72 & 71.3 & 65 & 63.1 & 89 & 64.0 & 261 & 64.1 & 14.591 & $0.024^{*}$ \\
\hline 65 and over & 14 & 21.9 & 11 & 10.9 & 15 & 14.6 & 9 & 6.5 & 49 & 12.0 & & \\
\hline Marital Status & & & & & & & & & & & & \\
\hline Married & 41 & 64.1 & 70 & 69.3 & 49 & 47.6 & 70 & 50.4 & 230 & 56.5 & 17011 & $0000^{* * *}$ \\
\hline Single & 23 & 35.9 & 31 & 30.7 & 54 & 52.4 & 69 & 49.6 & 177 & 43.5 & $1 / .011$ & \\
\hline Education & & & & & & & & & & & & \\
\hline Primary School & 18 & 28.1 & 38 & 37.6 & 52 & 50.5 & 65 & 46.8 & 173 & 42.5 & & \\
\hline High School & 16 & 25.0 & 31 & 30.7 & 29 & 28.2 & 40 & 28.8 & 116 & 28.5 & & \\
\hline Associate Degree & 12 & 18.8 & 18 & 17.8 & 12 & 11.7 & 24 & 17.3 & 66 & 16.2 & 051 & $011^{*}$ \\
\hline $\begin{array}{l}\text { Bachelor's } \\
\text { Degree }\end{array}$ & 14 & 21.9 & 10 & 9.9 & 9 & 8.7 & 9 & 6.5 & 42 & 10.3 & 5.951 & 0.011 \\
\hline Postgraduate & 4 & 6.3 & 4 & 4.0 & 1 & 1.0 & 1 & 0.7 & 10 & 2.5 & & \\
\hline
\end{tabular}


Akmeşe, K., A., Özata, E., Sormaz, Ü. / Journal of Yasar University, 2020, 15/58, 177-189

\begin{tabular}{|l|c|c|c|c|c|c|c|c|c|c|c|c|}
\hline TOTAL & 64 & 15.7 & 101 & 24.8 & 103 & 25.3 & 139 & 34.2 & 407 & 100.0 & & \\
\hline
\end{tabular}

When the demographic findings are analyzed, it is observed that male employees dominate, as in many other sectors, the field of gastronomy, which is the taste-oriented area of tourism. The intensity of male employees in the area of gastronomy and culinary activities, which is indeed expected to be dominated by female employees, explains the fact that men are at the forefront in cookery. Beyond gender discrimination, the fact that women's involvement in the economy as a labor force remains limited even in the kitchen-related areas is one of the demographic findings in the study that shed light on the economic and social structure of the society.

Another demographic finding is that approximately one quarter of those who prefer to work in the field of gastronomy are university graduates. Most of those working in this field have primary and secondary education. However, the education opportunities in the field of gastronomy and tourism at secondary education level and the fact that employees with university degree constitute approximately twenty-five percent of the overall employees indicate that those working the field of gastronomy are well-educated and qualified employees. The higher number of employees with a university degree in 5-star hotels and food and beverage/entertainment facilities indicates that those studied in the field of gastronomy have higher awareness now and that large-scale and high-quality facilities prefer to work with individuals with high education.

Table 3 presents the data on vocational experience levels of respondents. As a result of data analysis, it was observed that $35.9 \%$ of respondents have not had any vocational education, $31.4 \%$ have worked in five and more different working places, and $32.9 \%$ have been working in the sector for 20 years and more. As the data were analyzed statistically, the difference among respondents' vocational education levels was found to be significant on group basis $(\mathrm{p}<0.01)$.

Table 3. Vocational Experience

\begin{tabular}{|c|c|c|c|c|c|c|c|c|c|c|c|c|}
\hline & & 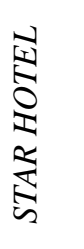 & & 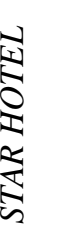 & & 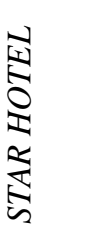 & o & 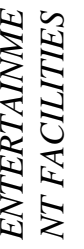 & & $\frac{J}{\delta}$ & $X^{2}$ & $p$ \\
\hline & $\mathrm{n}$ & $\%$ & $\mathrm{n}$ & $\%$ & $\mathrm{n}$ & $\%$ & $\mathrm{n}$ & $\%$ & $\mathrm{n}$ & $\%$ & & \\
\hline \multicolumn{11}{|l|}{$\begin{array}{l}\text { Vocational Education } \\
\text { Level }\end{array}$} & \multirow{5}{*}{22.523} & \multirow{5}{*}{$0.007^{* *}$} \\
\hline No vocational education & 20 & 31.3 & 34 & 33.7 & 42 & 40.8 & 50 & 36.0 & 146 & 35.9 & & \\
\hline Vocational high school & 6 & 9.4 & 22 & 21.8 & 19 & 18.4 & 36 & 25.9 & 83 & 20.4 & & \\
\hline $\begin{array}{l}\text { Vocational Associate } \\
\text { Degree/Bachelor's }\end{array}$ & 28 & 43.8 & 32 & 31.7 & 19 & 18.4 & 29 & 20.9 & 108 & 26.5 & & \\
\hline $\begin{array}{l}\text { Owner of the proficiency/ } \\
\text { journeyman's certificate }\end{array}$ & 10 & 15.6 & 13 & 12.9 & 23 & 22.3 & 24 & 17.3 & 70 & 17.2 & & \\
\hline \multicolumn{13}{|c|}{ Number of Workplaces (Related with the profession) } \\
\hline One & 5 & 7.8 & 10 & 9.9 & 8 & 7.8 & 13 & 9.4 & 36 & 8.8 & \multirow{5}{*}{9.948} & \multirow{5}{*}{0.621} \\
\hline Two & 13 & 20.3 & 12 & 11.9 & 19 & 18.4 & 28 & 20.1 & 72 & 17.7 & & \\
\hline Three & 7 & 10.9 & 21 & 20.8 & 21 & 20.4 & 25 & 18.0 & 74 & 18.2 & & \\
\hline Four & 18 & 28.1 & 29 & 28.7 & 25 & 24.3 & 25 & 18.0 & 97 & 23.8 & & \\
\hline Five and more & 21 & 32.8 & 29 & 28.7 & 30 & 29.1 & 48 & 34.5 & 128 & 31.4 & & \\
\hline \multicolumn{13}{|l|}{$\begin{array}{l}\text { Year of Experience in the } \\
\text { Profession }\end{array}$} \\
\hline $1-5$ years & 3 & 4.7 & 5 & 5.0 & 3 & 2.9 & 8 & 5.8 & 19 & 4.7 & \multirow{5}{*}{7.792} & \multirow{5}{*}{0.801} \\
\hline 6-10 years & 11 & 17.2 & 13 & 12.9 & 14 & 13.6 & 19 & 13.7 & 57 & 14.0 & & \\
\hline 11-15 years & 10 & 15.6 & 28 & 27.7 & 21 & 20.4 & 27 & 19.4 & 86 & 21.1 & & \\
\hline $16-20$ years & 16 & 25.0 & 27 & 26.7 & 33 & 32.0 & 35 & 25.2 & 111 & 27.3 & & \\
\hline 20 years and more & 24 & 37.5 & 28 & 27.7 & 32 & 31.1 & 50 & 36.0 & 134 & 32.9 & & \\
\hline TOTAL & 64 & 15.7 & 101 & 24.8 & 103 & 25.3 & 139 & 34.2 & 407 & 100.0 & & \\
\hline
\end{tabular}

Based on the information in Table 3 about professional experience and educational background, it is seen that threequarters of the respondents have studied in the field of gastronomy or participated in gastronomy trainings. This is an important proportion. As in any sector, unqualified workforce exists in the gastronomy sector as well and it is needed for certain work. However, it is expected that the majority of the employees are qualified and trained in their field. When the professional experience, training and experience are evaluated within the framework of the research findings, it can be said that the units operating in the field of gastronomy have a powerful employee potential and prefer qualified employees. 
Table 4 presents the data on work information of respondents. In the light of the related data, it was observed that $50.6 \%$ of respondents work as department chief, $58.0 \%$ work in kitchen department and $38.8 \%$ have started their career in kitchen department. As the data were analyzed statistically, the difference among the departments where the respondents have started their career was found to be significant on group basis $(\mathrm{p}<0.001)$.

Table 4. Work Information

\begin{tabular}{|c|c|c|c|c|c|c|c|c|c|c|c|c|}
\hline & \multicolumn{2}{|c|}{ n } & \multicolumn{2}{|c|}{ 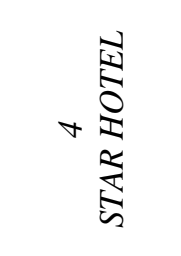 } & \multicolumn{2}{|c|}{ 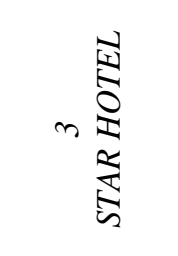 } & \multicolumn{2}{|c|}{ 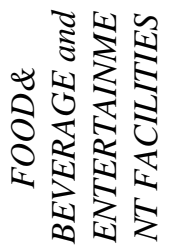 } & \multicolumn{2}{|c|}{$\frac{\sqrt{Z}}{6}$} & \multirow[t]{2}{*}{$X^{2}$} & \multirow[t]{2}{*}{$p$} \\
\hline & $\mathrm{n}$ & $\%$ & $\mathrm{n}$ & $\%$ & $\mathrm{n}$ & $\%$ & $\mathrm{n}$ & $\%$ & $\mathrm{n}$ & $\%$ & & \\
\hline \multicolumn{11}{|l|}{ Position } & \multirow{5}{*}{13.036} & \multirow{5}{*}{0.161} \\
\hline Department Chief & 33 & 51.6 & 40 & 39.6 & 57 & 55.3 & 76 & 54.7 & 206 & 50.6 & & \\
\hline Assistant Manager & 14 & 21.9 & 29 & 28.7 & 22 & 21.4 & 26 & 18.7 & 91 & 22.4 & & \\
\hline Department Manager & 4 & 6.3 & 17 & 16.8 & 13 & 12.6 & 21 & 15.1 & 55 & 13.5 & & \\
\hline General Manager & 13 & 20.3 & 15 & 14.9 & 11 & 10.7 & 16 & 11.5 & 55 & 3.5 & & \\
\hline \multicolumn{13}{|l|}{ Department } \\
\hline Kitchen & 30 & 46.9 & 56 & 55.4 & 68 & 66.0 & 82 & 59.0 & 236 & 58.0 & \multirow{3}{*}{7.488} & \multirow{3}{*}{0.278} \\
\hline Service & 21 & 32.8 & 30 & 29.7 & 24 & 23.3 & 41 & 29.5 & 116 & 28.5 & & \\
\hline Administrative Office & 13 & 20.3 & 15 & 14.9 & 11 & 10.7 & 16 & 11.5 & 55 & 13.5 & & \\
\hline \multicolumn{13}{|c|}{ First Department in Career } \\
\hline Kitchen & 23 & 35.9 & 41 & 40.6 & 40 & 38.8 & 54 & 38.8 & 158 & 38.8 & \multirow{9}{*}{57.601} & \multirow{9}{*}{$0.000^{* * * *}$} \\
\hline Steward & 10 & 15.6 & 12 & 11.9 & 21 & 20.4 & 38 & 27.3 & 81 & 19.9 & & \\
\hline Service & 23 & 35.9 & 17 & 16.8 & 28 & 27.2 & 39 & 28.1 & 107 & 26.3 & & \\
\hline Front office & 4 & 6.3 & 9 & 8.9 & 4 & 3.9 & 0 & 0.0 & 17 & 4.2 & & \\
\hline Technical service & 0 & 0.0 & 2 & 2.0 & 1 & 1.0 & 1 & 0.7 & 4 & 1.0 & & \\
\hline $\begin{array}{l}\text { Purchasing/Accountin } \\
g\end{array}$ & 0 & 0.0 & 2 & 2.0 & 3 & 2.9 & 5 & 3.6 & 10 & 2.5 & & \\
\hline Housekeeping & 0 & 0.0 & 5 & 5.0 & 1 & 1.0 & 0 & 0.0 & 6 & 1.5 & & \\
\hline Security & 0 & 0.0 & 4 & 4.0 & 1 & 1.0 & 0 & 0.0 & 5 & 1.2 & & \\
\hline Sales \& Marketing & 4 & 6.3 & 9 & 8.9 & 4 & 3.9 & 2 & 1.4 & 19 & 4.7 & & \\
\hline TOTAL & 64 & 15.7 & 101 & 24.8 & 103 & 25.3 & 139 & 34.2 & 407 & 100.0 & & \\
\hline
\end{tabular}

The analysis of the work information given in Table 4 concludes a finding that affects and supports the results and evaluations in the current study. The majority of the interviewed respondents work in the gastronomy and culinary departments, which fit the scope of the research in terms of the institutions and enterprises worked. Since the individuals working in the kitchen and service departments are supposed to have more realistic opinions about the professional qualifications and expectations, the findings will provide the desired and expected results of the research.

Table 5 presents the qualifications that the gastronomy industry expects to find in employees working in the field of gastronomy. Having analyzed the related data, it was observed that the most significant employee qualification was "work effort" (52.8\%), the most significant criterion for newcomers was "experience" (42.8\%), the most significant qualification for the employees in gastronomy industry was "experience" (42.0\%), and the most important skill category for career development was "food and beverage" (43.0\%). When the data were analyzed statistically, the difference among the criteria of the most significant employee qualification $(\mathrm{p}<0.001)$, the most significant criterion for newcomers $(p<0.001)$, the most significant qualification for the employees in gastronomy industry $(p<0.001)$ and the most important skill category for career development $(\mathrm{p}<0.001)$ was found to be significant on group basis. 
Akmeşe, K., A., Özata, E., Sormaz, Ü. / Journal of Yasar University, 2020, 15/58, 177-189

Table 5. Expected Qualifications of the Employees in the Field of Gastronomy

\begin{tabular}{|c|c|c|c|c|c|c|c|c|c|c|c|c|}
\hline & & 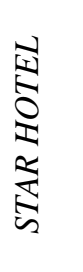 & & $\frac{\sqrt{x}}{0}$ & & 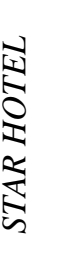 & 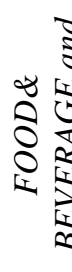 & 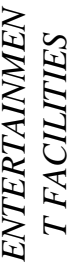 & & 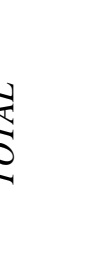 & $X^{2}$ & $p$ \\
\hline & $\mathrm{n}$ & $\%$ & $\mathrm{n}$ & $\%$ & $\mathrm{n}$ & $\%$ & $\mathrm{n}$ & $\%$ & $\mathrm{n}$ & $\%$ & & \\
\hline \multicolumn{11}{|c|}{ The most significant employee qualification } & \multirow{6}{*}{135.332} & \multirow{6}{*}{$\begin{array}{c}0.000^{* * *} \\
*\end{array}$} \\
\hline Work effort & 13 & 20.3 & 27 & 26.7 & 72 & 69.9 & 103 & 74.1 & 215 & 52.8 & & \\
\hline Enthusiasm for the job & 4 & 6.3 & 5 & 5.0 & 6 & 5.8 & 8 & 5.8 & 23 & 5.7 & & \\
\hline Willingness to learn & 9 & 14.0 & 14 & 13.9 & 13 & 12.6 & 17 & 12.2 & 53 & 13.0 & & \\
\hline Determination & 2 & 3.1 & 2 & 2.0 & 5 & 4.9 & 4 & 2.9 & 13 & 3.2 & & \\
\hline Specific skills & 36 & 56.3 & 53 & 52.5 & 7 & 6.8 & 7 & 5.0 & 103 & 25.3 & & \\
\hline The most significant cri & rion & fornel & omer & & & & & & & & & \\
\hline Sector knowledge & 5 & 7.8 & 4 & 4.0 & 14 & 13.6 & 7 & 5.0 & 30 & 7.4 & \multirow{5}{*}{203.072} & \multirow{5}{*}{$\begin{array}{c}0.000^{* * *} \\
*\end{array}$} \\
\hline Personality & 3 & 4.7 & 7 & 6.9 & 6 & 5.8 & 12 & 8.6 & 28 & 6.9 & & \\
\hline Specific skills & 30 & 46.9 & 58 & 57.4 & 7 & 6.8 & 12 & 8.6 & 107 & 26.3 & & \\
\hline Qualifications & 22 & 34.4 & 26 & 25.7 & 7 & 6.8 & 13 & 9.4 & 68 & 16.7 & & \\
\hline Experience & 4 & 6.3 & 6 & 5.9 & 69 & 67.0 & 95 & 68.3 & 174 & 42.8 & & \\
\hline \multicolumn{12}{|c|}{ The most significant qualification for the employees in gastronomy industry } & \\
\hline Sector knowledge & 4 & 6.3 & 7 & 6.9 & 5 & 4.9 & 7 & 5.0 & 23 & 5.7 & \multirow{7}{*}{212.264} & \multirow{7}{*}{$0.000^{* * *}$} \\
\hline Specific skills & 6 & 9.4 & 12 & 11.9 & 12 & 11.7 & 14 & 10.1 & 44 & 10.8 & & \\
\hline Personality & 7 & 10.9 & 8 & 7.9 & 8 & 7.8 & 12 & 8.6 & 35 & 8.6 & & \\
\hline Qualifications & 42 & 65.6 & 61 & 60.4 & 3 & 2.9 & 8 & 5.8 & 114 & 28.0 & & \\
\hline Experience & 3 & 4.7 & 7 & 6.9 & 67 & 65.0 & 94 & 67.6 & 171 & 42.0 & & \\
\hline Approach & 1 & 1.6 & 3 & 3.0 & 7 & 6.8 & 2 & 1.4 & 13 & 3.2 & & \\
\hline Enthusiasm for the job & 1 & 1.6 & 3 & 3.0 & 1 & 1.0 & 2 & 1.4 & 7 & 1.7 & & \\
\hline \multicolumn{11}{|c|}{ The most important skill category for your career development } & \multirow{8}{*}{123.405} & \multirow{8}{*}{$\begin{array}{c}0.000^{* *} \\
*\end{array}$} \\
\hline Communication & 4 & 6.3 & 6 & 5.9 & 5 & 4.9 & 9 & 6.5 & 24 & 5.9 & & \\
\hline Taking initiative & 5 & 7.8 & 13 & 12.9 & 7 & 6.8 & 11 & 7.9 & 36 & 8.8 & & \\
\hline Human relations & 28 & 43.8 & 55 & 54.5 & 10 & 9.7 & 11 & 7.9 & 104 & 25.6 & & \\
\hline Food \& Beverage & 18 & 28.1 & 10 & 9.9 & 59 & 57.3 & 88 & 63.3 & 175 & 43.0 & & \\
\hline Problem solving & 3 & 4.7 & 7 & 6.9 & 11 & 10.7 & 7 & 5.0 & 28 & 6.9 & & \\
\hline Self-determination & 3 & 4.7 & 4 & 4.0 & 7 & 6.8 & 8 & 5.8 & 22 & 5.4 & & \\
\hline $\begin{array}{l}\text { Speaking Multiple } \\
\text { Languages }\end{array}$ & 3 & 4.7 & 6 & 5.9 & 4 & 3.9 & 5 & 3.6 & 18 & 4.4 & & \\
\hline TOTAL & 64 & 15.7 & 101 & 24.8 & 103 & 25.3 & 139 & 34.2 & 407 & 100.0 & & \\
\hline
\end{tabular}

The gastronomy industry predominantly expects work effort from the employees working in the sector. Willingness and diligence will ensure that the yielded outcomes are of a higher quality and sustainable. One of the most important ways of achieving customer satisfaction in the gastronomy and tourism industry, which is a service-oriented sector and where customer satisfaction occurs immediately and the interaction with the customer is quite rapid, is to find qualified and dedicated employees. In this way, enterprises will ensure sustainability within the industry by way of creating permanent customer satisfaction without losing their innovative nature and without compromising on quality.

Analyzing the findings in Table 5, it is seen that 'experience' is the sector professionals' greatest expectation from newcomers. In addition, skills in food and beverage-related matters come to the forefront as an important criterion in the context of kitchen. Even though the gastronomy and culinary industry is a field allowing learning by practicing, experienced and skilled personnel are of great importance for serial, satisfactory and high quality production processes. At this point, expectation of experience from a newcomer may raise a question in the minds. On the other hand, many institutions and universities that provide education in gastronomy-related areas encourage internship and on-the-job training programs and practical training for students. This provides students and newcomers with the opportunity of gaining experience. The results of the current study regarding the qualifications expected from the employees highlight the importance of on-the-job trainings and internships in the context of the gastronomy industry.

Table 6 presents the gastronomy industry's views on the department of gastronomy and culinary arts. Having analyzed the related data, it was found that the employees in 5-star hotels (3.58 \pm 1.31$)$, 4-star hotels (3.93 \pm 0.84$)$, 3-star hotels $(3.65 \pm 1.27)$ and the food \& beverage and entertainment facilities (3.78 \pm 1.15$)$ did not agree with the statement of "lecturers in gastronomy department are well-knowledgeable about the gastronomy industry"; that the employees in 5- 
star hotels (2.11 \pm 1.17$)$, 4-star hotels $(2.02 \pm 0.88)$ and the food \& beverage and entertainment facilities (2.10 \pm 1.01$)$ did agree; however, those in 3-star hotels (3.38 1.28$)$ did not agree with the statement of "Internship or on-the-job training programs are beneficial for the student's career"; that the employees in 5-star hotels (2.14 \pm 1.17$)$, 4-star hotels $(2.00 \pm 0.75)$ and the food \& beverage and entertainment facilities (2.27 \pm 1.01$)$ did agree; however, those in 3-star hotels (3.14 \pm 1.28$)$ did not agree with the statement of "there are differences between the expectations of sector managers and the lecturers"; that the employees in 5-star hotels (2.47 1.21$)$ and 4-star hotels (1.74 \pm 0.61$)$ did agree, however, those in 3 -star hotels (3.68 1.34$)$ and the food \& beverage and entertainment facilities (3.61 \pm 1.34$)$ did not agree with the statement of "To have a diploma degree is an important criterion in employee preferences". When the data were statistically analyzed, the difference among the criteria of "Internship or on-the-job training programs are beneficial for the student's career" $(\mathrm{p}<0.001)$, "there are differences between the expectations of sector managers and the lecturers" $(p<0.001)$ and "To have a diploma degree is an important criterion in employee preferences" ( $<<0.001)$ was found to be significant on group basis (Table 6).

Table 6. Views of Gastronomy Industry on the Department of Gastronomy and Culinary Arts

\begin{tabular}{|c|c|c|c|c|c|c|c|}
\hline & 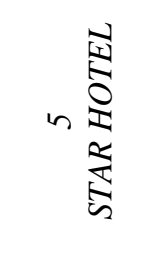 & 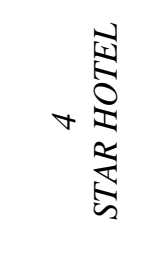 & 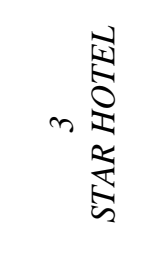 & 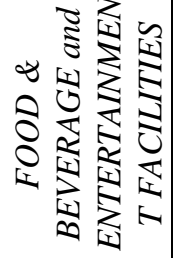 & $\frac{\sqrt[3]{k}}{6}$ & $F$ & $p$ \\
\hline & $\mathrm{M} \pm \mathrm{SS}$ & $\mathrm{M} \pm \mathrm{SS}$ & $\mathrm{M} \pm \mathrm{SS}$ & $\mathrm{M} \pm \mathrm{SS}$ & $\mathrm{M} \pm \mathrm{SS}$ & & \\
\hline $\begin{array}{l}\text { Lecturers in gastronomy } \\
\text { department are well- } \\
\text { knowledgeable about the } \\
\text { gastronomy industry }\end{array}$ & $3.58 \pm 1.31$ & $3.93 \pm 0.84$ & $3.65 \pm 1.27$ & $3.78 \pm 1.15$ & $3.75 \pm 1.15$ & 1.606 & 0.187 \\
\hline $\begin{array}{l}\text { Internship or on-the-job } \\
\text { training programs are } \\
\text { beneficial for the student's } \\
\text { career }\end{array}$ & $2.11 \pm 1.17$ & $2.02 \pm 0.88$ & $3.38 \pm 1.28$ & $2.10 \pm 1.01$ & $2.41 \pm 1.22$ & 37.387 & $0.000^{* * * *}$ \\
\hline $\begin{array}{l}\text { There are differences between } \\
\text { the expectations of sector } \\
\text { managers and the lecturers. }\end{array}$ & $2.14 \pm 1.17$ & $2.00 \pm 0.75$ & $3.14 \pm 1.28$ & $2.27 \pm 1.01$ & $2.40 \pm 1.14$ & 23.560 & $0.000^{* * * *}$ \\
\hline $\begin{array}{l}\text { To have a diploma degree is an } \\
\text { important criterion in } \\
\text { employee preferences }\end{array}$ & $2.47 \pm 1.21$ & $1.74 \pm 0.61$ & $3.68 \pm 1.34$ & $3.61 \pm 1.34$ & $2.99 \pm 1.42$ & 68.620 & $0.000^{* * * *}$ \\
\hline
\end{tabular}

The gastronomy and culinary arts departments of the universities are important units so that hotels and the enterprises which produce/offer food and beverages can reach qualified employees. In these departments, individuals who will work in the field of gastronomy are trained in an adequate and well-equipped manner. Table 6 presents the views of gastronomy professionals on the universities' gastronomy and culinary arts departments. The most striking finding on the Table is that professionals in the industry believe that the lecturers/trainers in the gastronomy departments are not sufficiently familiar with the sector. This factor may hinder the proper and adequate training of the potential workforce. This finding is worthy of being inquired and discussed. The benefits of internship and on-the-job training to students' future careers have been recognized by all actors in the industry. When questioned whether having a diploma degree is an important criterion in personnel recruitment, it is seen that large-scale 4 and 5-star hotels are sensitive about this matter. However, it has been concluded that 3 -star hotels and food and beverage/entertainment facilities do not recognize diploma degree as a criterion for employment. This result supports the findings in Table 3 which reflect the views on vocational experience. The findings in both tables emphasize the fact that large-scale enterprises have tendency towards individuals with high level of education in their employee preferences.

Table 7 presents the expectations of gastronomy industry from the students of the department of gastronomy and

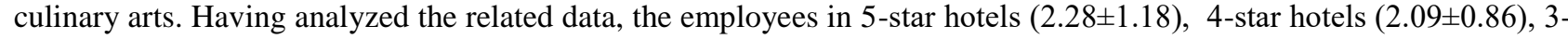
star hotels $(2.31 \pm 1.16)$ and the food \& beverage and entertainment facilities $(2.16 \pm 1.19)$ did agree with the statement of "To have specific qualifications (capability or competency) on performing a specific job"; that the employees in 5-star hotels $(2.23 \pm 1.17)$, 4 -star hotels $(2.71 \pm 1.28)$ and the food \& beverage and entertainment facilities $(2.96 \pm 1.38)$ did agree; however, those in 3-star hotels (3.32 \pm 1.42$)$ did not agree with the statement of "To achieve a high level of business success in the unit they work for"; that the employees in 5-star hotels (2.31 11.22$)$, 4-star hotels (2.66 \pm 1.13$)$ and the food $\&$ beverage and entertainment facilities (2.97 \pm 1.36$)$ did agree; however, those in 3 -star hotels (3.35 \pm 1.34$)$ did not agree with the statement of "To show determination and putting in effort in a way to prove their willingness to work"; that the employees in 5-star hotels $(2.41 \pm 1.18)$ and 4-star hotels $(2.68 \pm 1.16)$ did agree; however, those in 3-star hotels $(3.27 \pm 1.37)$ 
and the food \& beverage and entertainment facilities (3.02 \pm 1.35$)$ did not agree with the statement of "To be wellknowledgeable about the gastronomy industry"; that the employees in 5-star hotels (2.45 \pm 1.17$)$, 4-star hotels (2.79 \pm 1.21$)$ and the food \& beverage and entertainment facilities (2.99 \pm 1.42$)$ did agree; however, those in 3 -star hotels $(3.33 \pm 1.38)$ did not agree with the statement of "To have an efficient work performance"; that the employees in 5-star hotels (2.34 \pm 1.17$)$, 4-star hotels $(2.74 \pm 1.24)$ and the food \& beverage and entertainment facilities did agree; however, those in 3 -star hotels (3.23 \pm 1.37 ) did not agree with the statement of "To show an efficient performance in team work". When the data were statistically analyzed, the difference among the statements of "To achieve a high level of business success in the unit they work for" $(\mathrm{p}<0.001)$, "To show determination and putting in effort in a way to prove their willingness to work" $(p<0.001)$, "To be well-knowledgeable about the gastronomy industry" $(p<0.001)$, "To have an efficient work performance" and "To show an efficient performance in team work" $(\mathrm{p}<0.001)$ was found to be significant on group basis.

Table 7. Expectations of Gastronomy Industry from the Students of the Department of Gastronomy and Culinary Arts

\begin{tabular}{|l|c|c|c|c|c|c|}
\hline & & & &
\end{tabular}

In the light of the findings in Table 7, it is observed that 5 and 4-star hotels and food \& beverage/entertainment facilities have great expectations from students such as to be skilled in professional life, to be dedicated, to perform effectively in individual and team works, to have knowledge about the gastronomy industry and to achieve high success. On the other hand, 3-star hotels are more flexible on these matters. Flexible attitude of 3-star hotels can be grounded on the fact that their employee and customer volume is much lower and therefore they have less concern about organizational image. It can be claimed that the larger-scale and high-volume facilities demand qualified and well-equipped employees and expect students to develop themselves in this direction.

Table 8 presents the views of the gastronomy industry on graduation from the department of gastronomy. Having analyzed the related data, it was found that the employees in 5-star hotels (3.72 \pm 1.06$)$ and 4-star hotels (3.77 \pm 1.30$)$ did not agree; however, those in 3-star hotels $(2.36 \pm 1.29)$ and the food \& beverage and entertainment facilities $(2.39 \pm 1.28)$ did agree with the statement of "For a potential employee, job experience is much more important than having a diploma degree"; that the employees in 5-star hotels (2.31 \pm 1.11$)$ and 4-star hotels (2.26 \pm 1.19$)$ did agree; however, those in 3-star hotels (3.67 \pm 1.47$)$ and the food \& beverage and entertainment facilities (3.55 \pm 1.44$)$ did not agree with the statement of "To have a diploma degree in gastronomy contributes to the sector more than three-year job experience"; that the employees in 5-star hotels (2.27 \pm 0.98$)$ and 4-star hotels (2.37 \pm 1.20$)$ did agree; however, those in 3-star hotels (3.77 \pm 1.23$)$ and the food \& beverage and entertainment facilities (3.65 1.24$)$ did not agree with the statement of "For an employee with diploma degree in gastronomy, your organization provides various advantages"; that the employees in 5-star hotels $(2.23 \pm 1.08)$ and 4 -star hotels $(2.44 \pm 1.17)$ did agree; however, those in 3-star hotels $(3.76 \pm 1.18)$ and the food\& beverage and entertainment facilities (3.63 \pm 1.29$)$ did not agree with the statement of "Students having a bachelor's degree in relevant departments of the universities are employed with higher wages than those who do not have a university degree"; and that the employees in 5-star hotels (2.25 \pm 1.11$)$ and 4-star hotels (2.34 \pm 1.13$)$ did agree; however, those in 3-star hotels $(3.57 \pm 1.35)$ and the food \& beverage and entertainment facilities (3.59 \pm 1.35$)$ did not agree with the statement of "To have a bachelor's degree in gastronomy is a prerequisite of being promoted in gastronomy industry". When the data were statistically analyzed, the difference among the statements of "Having a diploma degree in gastronomy contributes 
to the sector more than three-year-job experience" ( $p<0.001)$, "For an employee with diploma degree in gastronomy, your organization provides various advantages" $(p<0.001)$, "Students having a bachelor's degree in relevant departments of the universities are employed with higher wages than those who do not have a university degree" ( $p<0.001)$ and "To have a bachelor's degree in gastronomy is a prerequisite of being promoted in gastronomy industry" was found to be significant on group basis.

Table 8. Views of Gastronomy Industry on Graduation from the Department of Gastronomy

\begin{tabular}{|c|c|c|c|c|c|c|c|}
\hline & 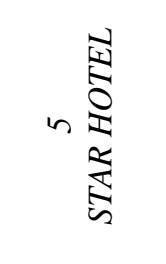 & $+\underset{\frac{1}{\vdots}}{\frac{1}{\vdots}}$ & 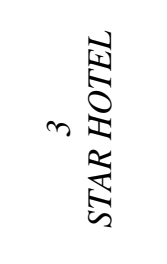 & 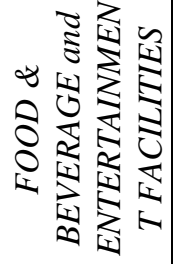 & $\begin{array}{l}\vdots \\
\vdots \\
\vdots \\
\vdots\end{array}$ & $F$ & $p$ \\
\hline & $\mathrm{M} \pm \mathrm{SS}$ & $\mathrm{M} \pm \mathrm{SS}$ & $\mathrm{M} \pm \mathrm{SS}$ & $\mathrm{M} \pm \mathrm{SS}$ & $\mathrm{M} \pm \mathrm{SS}$ & & \\
\hline $\begin{array}{l}\text { For a potential employee, job } \\
\text { experience is much more } \\
\text { important than having a } \\
\text { diploma degree }\end{array}$ & $3.72 \pm 1.06$ & $3.77 \pm 1.30$ & $2.36 \pm 1.29$ & $2.39 \pm 1.28$ & $2.94 \pm 1.42$ & 38.909 & $0.000^{* * * *}$ \\
\hline $\begin{array}{l}\text { To have a diploma degree in } \\
\text { gastronomy contributes to the } \\
\text { sector more than three-year } \\
\text { job experience }\end{array}$ & $2.31 \pm 1.11$ & $2.26 \pm 1.19$ & $3.67 \pm 1.47$ & $3.55 \pm 1.44$ & $3.06 \pm 1.49$ & 31.824 & $0.000^{* * * *}$ \\
\hline $\begin{array}{l}\text { For an employee with diploma } \\
\text { degree in gastronomy, your } \\
\text { organization provides various } \\
\text { advantages }\end{array}$ & $2.27 \pm 0.98$ & $2.37 \pm 1.20$ & $3.77 \pm 1.23$ & $3.65 \pm 1.24$ & $3.14 \pm 1.36$ & 43.752 & $0.000^{* * *}$ \\
\hline $\begin{array}{l}\text { Students having a bachelor's } \\
\text { degree in relevant departments } \\
\text { of the universities are } \\
\text { employed with higher wages } \\
\text { than those who do not have a } \\
\text { university degree }\end{array}$ & $2.23 \pm 1.08$ & $2.44 \pm 1.17$ & $3.76 \pm 1.18$ & $3.63 \pm 1.29$ & $3.15 \pm 1.37$ & 40.568 & $0.000^{* * * *}$ \\
\hline $\begin{array}{l}\text { To have a bachelor's degree in } \\
\text { gastronomy is a prerequisite of } \\
\text { being promoted in gastronomy } \\
\text { industry }\end{array}$ & $2.25 \pm 1.11$ & $2.34 \pm 1.13$ & $3.57 \pm 1.35$ & $3.59 \pm 1.35$ & $3.06 \pm 1.41$ & 33.606 & $0.000^{* * * *}$ \\
\hline
\end{tabular}

The most significant finding in Table 8 is that 4 and 5-star hotel managers attach great importance to diploma degrees to be achieved in the field of gastronomy. 3-star hotels and food \& beverage/entertainment facilities reflect a more flexible stance in terms of employees' educational background and having diploma degree in the field of gastronomy. These findings support the research findings in Table 3 and Table 6 . In all three tables, it is seen that 4 and 5-star hotel managers give weight to the matter of employee education. It is understood that 3 -star hotels and food \& beverage and entertainment facilities do not have strict criteria in the context of employee education. This may be related to the importance attached to the corporate image or may result from the complexity of the work. Large-scale enterprises consider that customer satisfaction is of vital importance for their operational sustainability and that employee qualifications play a significant role in ensuring customer satisfaction. Large-scale enterprises that adjust their practices and employee preferences in this direction adopt a more sensitive attitude on the matter of education. Enterprises with smaller scale and contented with regional recognition are more focused on instant functionality. For this reason, they expect employees to have strong skills; however, do not have great expectations related to education and academic degree.

\section{Conclusion and Recommendations}

As of the 2000s, many factors such as the proliferation of social media and the impact of social media contents on people, and accordingly, the changes in people's tastes and expectations, and the formation of new personality frames providing the opportunity for making something for oneself and attributing importance to individual tastes have led to significant changes in the structure of the tourism industry (Şahin, 2015: 77). With the desire to experience different cultures and daily life forms belonging to those cultures, tourists having adapted to globalization throughout this process have started to be interested in local intangible cultural properties and the local communities which reflect past cultures into their daily life routines, rather than visiting the structured cultural heritage of the past. As a consequence of the interest in question, 
new tourism types focusing on local intangible cultural properties have emerged and exhibited a rising trend in tourism. Many countries use their intangible cultural properties as a catalyst for the development of their underdeveloped regions (Çă̆l1, 2012: 1).

Gastronomy tourism is an activity that has attracted the attention of tourists in recent times by way of characterizing the most delicious form of intangible local cultural properties. It is emphasized that enterprises and employees offering services in the tourism industry should continuously revise themselves in order to ensure the sustainability of the interest of tourists.

Taking into consideration the analyses and findings in the current study, it is seen that professionals in the gastronomy industry focus on qualified, skilled, educated and dedicated individuals in their employee preferences. It has been observed that 4 and 5-star hotels, which provide a greater employment potential, prefer those who have studied and have had diploma degree in the field of gastronomy. This result supports the findings of the literature review (Tensone and Ricci, 2012, Gümüş, Arı and Bakırtaş, 2010). In addition, it was concluded that all actors in the industry expect employees to be experienced in the field. It is also observed that professionals in the gastronomy industry believe that the academic staff of the universities' gastronomy and culinary arts departments does not have sufficient awareness about the requirements of the real sector. This is a paradox for enterprises that are sensitive to the issue of diploma. Comprehensive and reciprocally interactive studies should be conducted to figure out this matter.

The results in the current study are compatible with the findings of other studies in the literature. This indicates that the expectations and constraints for the employees in the gastronomy industry are grounded on similar reasons and that the findings in the current study yield benefits for the literature.

In the light of the findings in the current study conducted with the purpose of identifying the gastronomy industry's expectations from the employees, it is recommended that:

- Employees should have self-motivation to work and put in effort, accordingly,

- Employees should enhance their experiences with the help of internship and on-the-job training programs,

- Employees should improve their skills on food and beverages with the help of relevant courses and trainings,

- Priority in employment of lecturers for universities' gastronomy departments should be given to the individuals who have practical knowledge, skills and experience in gastronomy industry,

- Lecturers in universities' gastronomy departments should be in constant communication and cooperation with the sector,

- The importance of diploma degree in gastronomy industry should be emphasized during the informative seminars on career opportunities to be organized by relevant ministries for the graduates of the Department of Gastronomy. 
Akmeşe, K., A., Özata, E., Sormaz, Ü. / Journal of Yasar University, 2020, 15/58, 177-189

\section{Teșekkür}

Bilgi, deneyim ve tecrübeleri ile çalışmanın daha nitelikli ve zengin bir içeriğe kavuşması konusunda desteklerini esirgemeyen Sayın Prof. Dr. Orhan İÇÖZ ve Sayın Doç. Dr. Meltem İNCE- YENILMEZ‘ e sonsuz teşekkürlerimizi sunariz. 


\section{REFERENCES}

Aydın, Ebru. 2015. Gastronomi Turizminin Şehir Markalaşmasına Etkisi: Afyonkarahisar İi Örneği. Afyonkocatepe Üniversitesi, Sosyal Bilimler Enstitüsü, Turizm İşletmeciliği ve Otelcilik Anabilim Dalı, Yüksek Lisans Tezi, Afyonkarahisar.

Büyüköztürk, Şener. 2010. Bilimsel Araştırma Yöntemleri. Pegem Akademi Yayıncılık: Ankara.

Can, Abdullah. 2014. SPSS ile Bilimsel Araştırma Süresince Nicel Veri Analizi, Pegem Akademi Yayıncılık: Ankara.

Chan, Sow Hup. \& Kuok, Oi Mei. 2011. "A Study of Human Resources Recruitment, Selection, and Retention Issues in the Hospitality and Tourism Industry in Macau”. Journal of Human Resources in Hospitality \& Tourism, 10 (4); 421-441.

Çağlı, Irmak Beril. 2012. Türkiye’de Yerel Kültürün Turizm Odaklı Kalkınmadaki Rolü: Gastronomi Turizmi Örneği. İstanbul Teknik Üniversitesi, Fen Bilimleri Enstitüsü, Şehir ve Bölge Planlama Anabilim Dalı, Bölge Planlama Programı, Yüksek Lisans Tezi, İstanbul.

Durlu-Özkaya, F. \& Can, A. 2012. "Gastronomi Turizminin Destinasyon Pazarlamasına Etkisi." Türk Tarım ve Hayvancılık Bakanlı̆̆ Dergisi, Temmuz-Ağustos, Sayı: 206.

Gheorghe, Georgică., Tudorache, Petronela., Nistoreanu, Puiu. 2014. "Gastronomic Tourism,A New Trend For Contemporary Tourism??" Cactus Tourism Journal, 12-21.

Ghiselli, Richard F., La Lopa, Joseph Mick. \& Bai, Billy. 2001. “Job satisfaction, life satisfaction, and turnover intent among food-service managers." Cornell Hotel and Restaurant Administration Quarterly, 42 (2); 28-37.

Gümüs, Şale. Arı, Merve. \& Bakırtas, Hülya. 2010. Otel İşletmelerinde Personel Seçimi: Bursa İlinde Bir Uygulama. MYO-OS 2010- Ulusal Meslek Yuksekokulları Oğrenci Sempozyumu, 21-22 Ekim 2010, Düzce.

Hall, Michael., Williams, Allen., Lew, Alan, A. 2004. "Tourism: Conceptualizations, Institutions, and Issues". A Companion to Tourism. Blackwell Publishing, 1-22.

Hegarty, Joseph A. \& O’Mahony, G. Barry. 2001. "Gastronomy: A Phenomenon of Cultural Expressionism and an Aesthetic for Living." International Journal of Hospitality Management, 20; 3-13.

Hegarty, Joseph A. 2005. "Developing "Subject Fields” in Culinary Arts, Science and Gastronomy”. Journal of Culinary Science and Technology, 4 (1); 5-13.

Hegarty, Joseph A. \& Antun, J.M. 2007. “Celebrate Culinary Science and Gastronomic Knowledge.” Journal of Culinary Science and Technology, 5 (4); 1-7.

İstanbul İl Kültür ve Turizm Müdürlüğü. 2019. İstanbul Turizm İstatistikleri Raporu Mart 2019, Erişim Tarihi: 08.05.2019, Erişim Adresi: http://www.istanbulkulturturizm.gov.tr/Eklenti/63270,mart-2019pdf.pdf?0

Kadir, Norsiah., Karim, Mohd, Zaini, Abd. (2009). "Demand for Tourism in Malaysia by UK and US Tourists: A Cointegration and Error Correction Model Approach". Advances in Tourism Economics New Developments. Physica-Verlag Heidelberg, 51-70.

Kim, Junge Hee Ginny. 2008. Career expectations and requirements of undergraduate hospitality students and the hospitality industry: An analysis of differences. Auckland University of Technology, School of Hospitality and Tourism, Master Thesis.

Kivela, Jakša., Crotts, John, C. 2006. “Tourism And Gastronomy:Gastronomy’S Influence On How Tourists Experience A Destination". Journal of Hospitality \& Tourism Research, 354-377.

Lickorish, Leonard, J., Jenkins, Carson, L. 1997. “An Introduction to Tourism”. Butterworth-Heinemann. Oxford.

Pelit, Elbeyi. Soybali, Hasan Hüseyin \& Ak, Serkan. 2017. "Termal Otel İşletmelerinde Personel Bulma, Seçme ve Personeli İşe Yerleştirme Sürecindeki Uygulamalar ve Sorunlar Üzerine Bir Araştırma: Afyonkarahisar Örneği.” Seyahat ve Otel Işletmeciliği Dergisi/ Journal of Travel and Hospitality Management, 14 (3); 53-73.

Sandybayev, Almaz. 2016. "Gastronomic Tourism as a Destination Attraction in Kazakhstan”. Case Studies Journal, 17 /www.casestudiesjournal.com/.

Santich, Barbara. 2004. "The Study of Gastronomy and its Relevance to Hospitality Education and Training" International Journal of Hospitality Management, 23; 15-24.

Scarpato, Rosario. 2003. Tourism and Gastronomy. Hjalager, A.M., Richards G.(Ed.), Taylor and Francis e-Library, Chapter 4, pp. 52-101.

Şahin, Esra. 2015. Bir Destinasyon Unsuru Olarak Yerel Gastronominin Marka Şehir pazarlamasında Etkileri: Gaziantep Örneği, Gaziantep Üniversitesi, Sosyal Bilimler Enstitüsü, Gastronomi ve Mutfak Sanatları Ana Bilim Dalı, Yüksek Lisans Tezi, Gaziantep.

Tesone, Dana V. \& Ricci, Peter 2012. "Hospitality expectations of entry-level college graduates: A preference for attitude over aptitude." European Journal of Business and Social Science. 1(6); 140-149.

Ural, Ayhan. \& Kılıç, İbrahim. 2013. Bilimsel Araştırma Süreci ve SPSS İle Veri Analizi, Detay Yayıncılık: Ankara.

Yılmaz, Gülay Özdemir. \& Gürol, Neşe Kafa. 2012. "Balıkesir İlinin Kırsal Turizm Potansiyelinin Değerlendirilmesi." KMÜ Sosyal ve Ekonomik Araştırmalar Dergisi, 14(23); 23-32. 